\title{
PENGARUH KEPERCAYAAN KONSUMEN TERHADAP MINAT BELI PRODUK PAKAIAN SECARA ONLINE
}

\author{
Riski Rosdiana ${ }^{1}$, lyus Akhmad Haris², Kadek Rai Suwena ${ }^{3}$ \\ Jurusan Pendidikan Ekonomi \\ Universitas Pendidikan Ganesha \\ Singaraja, Indonesia
}

\begin{abstract}
Email: rosdiana.rizki@undiksha.ac.id ${ }^{1}$, iyusharis55@gmail.com², kadek suwena@yahoo.co.id ${ }^{3}$
\end{abstract}

\begin{abstract}
Abstrak
Penelitian ini bertujuan untuk mengetahui pengaruh kepercayaan konsumen terhadap minat beli produk pakaian secara online dan seberapa besar pengaruh kepercayaan konsumen terhadap minat beli produk pakaian secara online. Subjek dalam penelitian ini adalah Mahasiswa Fakultas Ekonomi. Populasi dalam penelitian ini yaitu seluruh mahasiswa Fakultas Ekonomi Undiksha yang berjumlah 2.205 mahasiswa dan sampel ditentukan sebanyak 96 mahasiswa yang diambil dengan menggunakan teknik incidental sampling. Jenis data yang dikumpulkan adalah data kuantitatif dengan menggunakan metode kuisioner serta dianalis dengan menggunakan analisis regresi sederhana. Hasil penelitian menunjukkan bahwa terdapat pengaruh positif variabel kepercayaan konsumen terhadap minat beli produk pakaian secara online. Berdasarkan hasil uji parsial diperoleh t hitung sebesar 2,938 dan koefisien regresi 1,296 dengan signifikansi 0,004. Dengan demikian, dapat disimpulkan bahwa kepercayaan konsumen berpengaruh positif dan signifikan terhadap minat beli produk pakaian secara online sebesar $29,6 \%$.
\end{abstract}

Kata kunci: Kepercayaan Konsumen dan Minat Beli

\begin{abstract}
This research aims to know the influence of consumer confidence towards the interest to buy online and how muchinfluence consumer confidence towards the interest to buy online. The subject in this study was students. The population in this study were all students of Ganesha University of Education in the Faculty of Economic totaling 2.205 students and a sample of 96 students were taken using incidental sampling technique. The type of data collected is quantitative data using a detailed quisionnaire and analysis using simple regression analysis. The result showed that there is a positive influence on cunsumor confidence against variable interest buy products clothing online. Based on test result obtained partial $t$ calculate regression coeeficient of 2,938 and 1,296 by 0,004 significance. Thus, it can be concluded that consumer confidence is positive and significant effect against the interest in buying clothing online product amounted to 29,6 .
\end{abstract}

Keyword: consumer confidence and purchasing interest 


\section{PENDAHULUAN}

Di era industri ini, masyarakat dimanjakan dengan kemudahan mendapatkan barang dan jasa yang akan memenuhi kebutuhan mereka. Dengan merebaknya berbagai industri di Indonesia membuat masyarakat menjadi semakin konsumtif. Perusahaan semakin bersaing menarik pelanggan dan memperluas daerah pengembangan bisnisnya, misalnya dengan memanfaatkan kecanggihan teknologi dan internet. Internet adalah salah satu produk jasa yang sangat mudah dioperasikan dan dapat digunakan oleh semua kalangan dan dapat digunakan sepanjang waktu (setiap saat) dengan menggunakan electritic commerce (ecommerce) untuk memasarkan dan membeli berbagai macam produk atau jasa, baik dalam bentuk fisik maupun digital. Dengan adanya internet, perusahaan dapat menjual produk dan jasanya melalui internet dengan secara langsung (B2C) atau melalui bisnis lainnya (B2B) yang disebut dengan e-commerce atau $e$ marketing.

Perkembangan dunia internet menawarkan banyak manfaat dalam dunia bisnis dan kehidupan. Internet telah memengaruhi cara-cara bisnis dan perilaku konsumen saat ini. Nilai-nilai yang ditawarkan perusahaan kepada konsumen perlu dirancang kembali agar dapat menyesuaikan dengan perilaku konsumen yang telah bergeser karena adanya internet. Pencarian informasi, membeli serta menggunakan jasa dapat dilakukan di internet. Perilaku generasi internet atau populer disebut generasi milienalis yang sangat berbeda dengan generasi sebelumnya tentu memerlukan pemahaman yang lebih mendalam agar dapat merancang strategi pemasaran yang tepat untuk kelompok yang telah terpengaruh internet saat ini.

Perkembangan teknologi internet telah mengubah berbagai aspek kehidupan termasuk perilaku konsumen. Perubahan cara memperoleh informasi, kebutuhan mengambil keputusan dengan cara yang cepat tanpa terikat ruang dan waktu. Kebutuhan untuk mengaktualisasikan diri di dunia maya berdampak secara tidak langsung maupun secara langsung terhadap perilaku konsumen dalam membeli dan mengkonsumsi produk. Pengguna internet yang terus bertambah menjadi pasar baru yang cukup potensial bagi perusahaan. Internet adalah salah satu produk jasa yang sangat mudah dioperasikan dan dapat digunakan oleh semua kalangan dan dapat digunakan sepanjang waktu (setiap saat). Kelebihan itulah yang menjadi salah satu faktor pendorong berkembangnya internet di seluruh dunia. Penggunaan internet sudah menjadi sebuah gaya hidup bagi sebagian penduduk di dunia, demikian juga halnya yang terjadi di Indonesia.

Era perkembangan teknologi yang semakin pesat dewasa ini membuat persaingan bisnis dalam bidang apapun menjadi lebh variatif. Banyak metode bisnis yang dilakukan oleh sebuah perusahaan untuk menarik konsumen sebanyakbanyaknya (Kotler, 2004, p3). Perkembangan teknologi dan perkembangan internet melahirkan perkembangan bisnis jaringan atau yang sering disebut dengan istilah E-Commerce atau Online Shop yang lebih memudahkan konsumen mendapatkan barang atau jasa yang diinginkan. Perkembangan ECommerce atau Online Shop juga tidak lepas dari perilaku konsumen dalam melakukan pembelian online. Setiap konsumen mempunyai alasan yang berbeda-beda dalam melakukan pembelian. Alasan-alasan tersebut antara lain karena konsumen senang melakukan pembelian impulsif, orientasi merek, orientasi kualitas, kepercayaan online, pengalaman pembelian online sebelumnya.

Berkembangnya bisnis e-commerce di Indonesia telah merubah beberapa perilaku konsumen salah satunya adalah kebiasaan berbelanja di pusat perbelanjaan atau toko sekarang mulai beralih dengan menggunakan media online. Selama terkoneksi dengan internet, konsumen tidak harus mendatangi toko atau tempat perbelanjaan untuk mendapatkan barang atau jasa yang diinginkannya. Banyaknya perusahaan e-commerce yang ada di Indonesia, serta beragam jenis layanan yang di tawarkan membuat para konsumen lebih leluasa dalam memilih toko online mana yang ingin mereka kunjungi. 
Banyaknya perusahaan e-commerce yang ada di Indonesia menyebabkan kompetisi yang ketat untuk menarik minat seseorang untuk berkunjung dan melakukan pembelian melalui situs miliknya. Banyaknya perusahaan ecommerce yang muncul beberapa tahun kebelakang menunjukkan bahwa pasar di Indonesaia sangat potensial. Hal ini di disebabkan karena masyarakat di Indonesia mulai tertarik dan berminat menggunakan layanan e-commerce yang ada, misalnya untuk melakukan pembelian melalui situs online atau online shop.

Perkembangan Online Shop atau toko online melalui media internet sudah menjamur di Indonesia, bahkan sudah sangat dikenal baik oleh khalayak ramai khususnya mahasiswa. Banyaknya beragam kemudahan dalam berbelanja dan bermacam jenis produk dan jasa yang ditawarkan, membuat masyarakat Indonesia menjadikan Online Shop sebagai salah satu "tempat berbelanja" baru selain pusat perbelanjaan. Hal ini membuat banyak penjual Online Shop yang berlomba - lomba menawarkan produknya dengan berbagai cara untuk menarik konsumen berbelanja, mereka memanfaatkan keadaan dimana Online Shopping sedang diminati oleh masyarakat Indonesia sampai saat ini. Menurut Arwiedya (2011), menjamurnya Online Shop membuka peluang usaha dalam bidang produk fashion di internet yang banyak membidik remaja sebagai konsumennya. Keunggulan bisnis Online Shop selain mudah dalam melakukan promosi, juga sangat efisien karena hanya membutuhkan biaya berlangganan internet untuk dapat menjalankan bisnisnya.

Dengan mudahnya mengakses internet dimasa globalisasi seperti pada saat ini, dimana jarak antara satu dengan yang lain semakin kabur dan tidak terbatas. Keadaan ini tentu menyebabkan persaingan antara usaha online untuk berlomba-lomba dalam memberikan kemudahan, dan keyakinan dalam berbelanja online. Penjualan online tentu juga berkaitkan dengan produk yang ditawarkan oleh online shop itu sendiri. Jika kualiatas suatu produk yang di jual diketahui konsumen mengenai kualitasnya yang bagus dan sesuai harapan, maka akan menarik minat konsumen untuk membeli melalui online.

Keberhasilan bisnis online tidak

lepas dari minat konsumen untuk melakukan pembelian atau belanja online. Tentunya minat konsumen untuk melakukan pembelian atau belanja online dipengaruhi oleh beberapa faktor seperti kepercayaan konsumen terhadap reseller atau pelaku penjualan online. Penelitian ini dilakukan untuk mengetahui faktor-faktor apa yang dapat mempengaruhi niat konsumen untuk melakukan pembelian atau belanja online.

Minat adalah intensi, didefinisikan secara umum sebagai suatu keinginan mendalam untuk melakukan sesuatu yang disukai. Seorang individu yang mengetahui informasi tentang situs online dapat membuatnya tertarik untuk melakukan sesuatu yang berhubungan dengan online tersebut yang menimbulkan rasa ketertarikannya, itulah yang disebut sebagai niat pembelian secara online. Minat merupakan ketertarikan konsumen terhadap suatu produk dengan mencari informasi tambahan. Seorang konsumen yang mulai timbul minatnya akan terdorong untuk mengetahui kualitas toko online, kemudian konsumen akan membangun kepercayaan atas hasil informasi yang didapat dan mempertimbangkan risiko yang dapat ditimbulkan (Setiadi, 2008).

Minat beli merupakan rasa ketertarikan yang dialami oleh konsumen terhadap suatu produk (barang/jasa) yang dipengaruhi oleh sikap diluar konsumen dan di dalam konsumen itu sendiri (Ashari, 2012). Minat merupakan kecenderungan hati yang tinggi terhadap sesuatu yang timbul karena kebutuhan, yang dirasa atau tidak dirasakan atau keinginan hal tertentu. Minat dapat diartikan kecenderungan untuk dapat tertarik atau terdorong untuk memperhatikan seseorang sesuatu barang atau kegiatan dalam bidang-bidang tertentu. Karena minat terhadap sesuatu yang diinginkan, maka muncul keinginan untuk membeli. Disisi lain, minat beli merupakan sesuatu yang berhubungan dengan rencana konsumen untuk membeli produk tertentu serta berapa banyak unit produk yang dibutuhkan pada periode 
tertentu. Dapat dikatakan bahwa minat beli merupakan pernyataan mental dari konsumen yang merefleksikan rencana pembelian sejumlah produk dengan merek tertentu. Hal ini sangat diperlukan oleh para pemasar untuk mengetahui minat beli konsumen terhadap suatu produk, baik para pemasar maupun ahli ekonomi menggunakan variabel minat untuk memprediksi perilaku konsumen dimasa yang akan datang.

Schiffman dan Kanuk (2007:201) menyatakan bahwa minat merupakan salah satu aspek psikologis yang memiliki pengaruh cukup besar terhadap sikap perilaku. Penilaian konsumen terhadap produk tergantung pada pengetahuannya akan informasi tentang fungsi sebenarnya dari produk tersebut, dengan demikian konsumen yang berminat untuk melakukan pembelian suatu produk dipengaruhi oleh informasi yang diterima. Minat beli menurut Kotler dan Keller (2008) adalah bagian dari komponen perilaku konsumen dalam sikap mengkonsumsi, kecenderungan responden untuk bertindak sebelum keputusan benar benar dilaksanakan. Minat yang muncul dalam melakukan pembelian menciptakan suatu motivasi yang terus terekam dalam benaknya dan menjadi suatu kegiatan yang sangat kuat yang pada akhirnya ketika seorang konsumen harus memenuhi kebutuhanya akan mengaktualisasikan apa yang ada didalam benaknya itu. Komponen minat berisikan niat untuk melakukan perilaku tertentu. Secara teoritis, terbentuknya minat tersebut ditentukan oleh interaksi kedua komponen yang mendahuluinya yaitu sikap terhadap perilaku dan norma subyektif tentang perilaku tersebut (Kussujaniatun, 2001:112).

\section{Minat beli konsumen sebagian}

besar dipengaruhi oleh kepercayaan konsumen itu sendiri. Agar dapat menarik minat konsumen untuk berkunjung dan bertransaksi melalui situsnya, perusahaan e-commerce harus membangun kepercayaan yang tinggi terhadap calon pembeli. Kepercayaan merupakan pondasi yang kuat untuk menentukan sukses atau tidaknya e-commerce kedepan. Ketika seorang yang ingin melakukan transaksi secara online, maka hal utama yang diperhatikan adalah reputasi toko online itu sendiri. Menurut Kotler dan Amstorng (2014: 135), bahwa karakteristik pembelian konsumen dipengaruhi kuat oleh budaya, sosial, personal, dan karakteristik psikologis. Faktor psikologis merupakan pemilihan pembelian seseorang yang dipengaruhi oleh empat faktor psikologis utama yaitu motivasi, persepsi, pembelajaran, dan kepercyaan serta sikap.

Keberhasilan transaksi di internet besar dipengaruhi oleh adanya faktor kepercayaan (Pavlou, 2003). Menurut Kurniawan (2011) Kepercayaan merupakan faktor utama timbulnya minat beli konsumen secara online. Faktor yang sangat penting dalam mempengaruhi pembelian online adalah kepercayaan. Kepercayaan menjadi faktor kunci dalam setiap transaksi jual beli secara online. Berdasarkan pendapat tersebut, dapat disimpulkan bahwa kepercayaan terhadap situs E-commerce merupakan faktor utama dalam memicu minat konsumen untuk melakukan pembelian secara online.

$$
\text { Menurut Sunarto (2009:153) }
$$

Kepercayaan konsumen (Consumen Beliefs) adalah semua pengetahuan yang dimiliki oleh konsumen dan semua kesimpulan yang dibuat konsumen tentang objek, atribut, dan manfaatnya. Objek (Objects) dapat berupa produk, orang, perusahaan, dan segala sesuatu, dimana seseorang memiliki kepercayaan dan sikap. sedangkan Atribut (Attributes) adalah karakteristik atau fitur yang mungkin dimiliki atau tidak dimiliki oleh objek. Sedangkan Manfaat (Benifits) adalah hasil positif yang diberikan atribut kepada konsumen. Para manajer harus menyadari bahwa kepercayaan terhadap objek, atribut, dan manfaat menunjukkan persepsi konsumen, dan karena itu, umumya kepercayaan seorang konsumen berbeda dengan konsumen lainnya.

Kepercayaan konsumen pada suatu produk dapat diciptakan dengan memberikan/ menyampaikan produk sesuai dengan spesifikasi yang diiklankan dalam website perusahaan. Saat konsumen menerima barang atau jasa yang sesuai dengan iklan perusahaan di website, maka akan menumbuhkan rasa percaya 
konsumen pada perusahaan. Kepercayaan konsumen dapat pula diciptakan dengan kejujuran produsen atau pemasar dalam menyampaikan karakteristik produk atau jasa layanan yang dijual dengan detail kepada konsumen. Selain itu, pemberian jaminan atau garansi dari perusahaan atau pemasar (seperti: penukaran atau penggantian barang karena rusak, servis atas produk yang rusak pasca pemakaian) kepada konsumen pasca pembelian produk juga akan memberikan kontribusi pada tingkat kepercayaan konsumen. Minimnya kepercayaan konsumen terhadap situs/website mengakibatkan konsumen takut untuk melakukan pembelian secara online. Kecenderungan konsumen untuk berbelanja melalui Online Shop mengurangi tingkat kewaspadaan dalam melakukan transaksi jual beli. Terbukti dengan banyaknya kasus penipuan dengan modus Online Shopping. Terutama disebabkan karena pembeli tidak dapat bertatap muka secara langsung dengan penjual, sehingga sistem kepercayaan menjadi modal utama dalam setiap transaksi jual beli online. Beberapa modus penipuan yang marak terjadi di Online Shopping, misalnya penjual yang menghilang setelah pembeli melakukan pembayaran, barang yang dikirim tidak sesuai dengan yang dijanjikan atau tidak sesuai dengan gambar yang ada di Online Shop tersebut. Pada online shop, konsumen berinteraksi melalui dunia maya sehingga online shop dipersepsikan akan lebih berisiko untuk terjadinya kejadiankejadian yang tidak diinginkan seperti penipuan.

Berdasarkan latar belakang masalah di atas maka peneliti tertarik untuk mengetahui yaitu pertama, kepercayaan konsumen terhadap minat beli produk pakaian secara online. Kedua, seberapa besar kepercayaan konsumen terhadap minat beli produk pakaian secara online.

\section{METODE PENELITIAN}

Jenis penelitian yang digunakan adalah penelitian kausal. penelitian kausal merupakan penelitian sebab-akibat yang menjelaskan pengaruh antara suatu variabel terhadap variabel lainnya yang digunakan untuk menjawab permasalahan melalui pengujian hipotesis (Sugiyono,
2010:56). Pada penelitian ini variabel yang dipergunakan dibagi menjadi dua bagian yaitu variabel bebas dan variabel terikat. Variabel bebas yang dipergunakan dalam penelitian ini adalah kepercayaan konsumen, sedangkan variabel terikat yang dipergunakan adalah minat beli produk pakaian secara online.

Menurut Sugiyono (2013), populasi adalah wilayah generalisasi yang terdiri atas obyek atau subyek yang mempunyai kualitas dan karakteristik tertentu yang ditetapkan oleh peneliti untuk dipelajari dan kemudian ditarik kesimpulannya. Dalam penelitian ini, populasi digunakan untuk menyebutkan seluruh elemen dari suatu wilayah yang menjadi sasaran penelitian atau merupakan keseluruhan (universum) dari objek penelitian, kemudian dari populasi tersebut akan diambil beberapa sampel. Populasi dalam penelitian ini adalah seluruh mahasiswa aktif di Fakultas Ekonomi Undiksha yang berjumlah 2.205 Mahasiswa.

Sampel adalah bagian dari jumlah dan karakteristik yang dimiliki oleh populasi tersebut. Dalam penelitian ini ukuran sampel akan menggunakan formula yang dikembangkan oleh slovin yakni dengan rumus sebagai berikut:

$$
\begin{aligned}
& \mathrm{n}=\frac{N}{1+y^{2}} \\
& (\text { Umar, 1998) } \\
& \mathrm{n}=\frac{2.205}{1+2.205(10 \%)^{2}} \\
& \mathrm{n}=\frac{2.205}{23.05} \\
& \mathrm{n}=95,661 \text { dibulatkan = 96 mahasiswa }
\end{aligned}
$$

Jadi, sampel penelitian yang digunakan untuk mewakili populasi penelitian berjumlah 96 mahasiswa. Sedangkan instrumen pengumpulan data dilakukan dengan kuisioner. Metode kuisioner adalah metode yang menggunakan sejumlah pertanyaan tertulis yang digunakan untuk memperoleh informasi dari responden dalam arti laporan tentang pribadinya atau hal-hal yang ia ketahui (Arikunto, 2002: 126). Skala pengukuran yang digunakan adalah skala Likert dengan empat alternatif jawaban. Variabel dalam penelitian yang telah ditetapkan akan dijabarkan menjadi 
indikator, dan dari indikator ini kemudian dijabarkan sebagai titik tolak untuk menyusun item intrumen yang kemudian diubah dalam beberapa pertanyaan yang selanjutnya dijawab oleh responden.

Kuisioner tersebut diberikan kepada para responden dan kemudian diharapkan setiap masing-masing responden akan mengisinya dengan pendapat dan persepsi setiap individu responden itu sendiri. Data dikumpulkan melalui kuisioner kemudian dilakukan skala pengukuran dan pemberian skor.
Dalam penelitian ini jawaban yang diberikan oleh konsumen kemudian diberi skor dengan mengacu pada skala likert. Menurut Sugiyono (2000: 86) skala likert digunakan untuk mengukur sikap, pendapat, dan persepsi seseorang atau sekelompok orang tentang fenomena sosial. Maka variabel yang dapat diukur dijabarkan menjadi indikator jawaban seperti item instrumen yang menggunakan skala likert. Sebelum kuisioner disebarkan kepada responden, kuisioner akan diuji terlebih dahulu. Adapun pengujian yang dipergunakan adalah sebagai berikut.

Tabel 1 Pengukuran Skala Likert

\begin{tabular}{lc}
\hline Jawaban Responden & Skor \\
\hline Setuju & 5 \\
\hline Kurang Setuju & 4 \\
\hline Tidak Setuju & 3 \\
\hline Sangat Tidak Setuju & 2 \\
\hline Sangat Setuju & 1 \\
\hline \hline
\end{tabular}

Pertama, Uji Validitas. Menurut Sugiyono (2005: 109) valid berarti instrument tersebut dapat digunakan untuk mengukur suatu penelitian. Suatu instrument dikatakan valid apabila mampu mengukur apa yang diinginkan serta dapat mengungkap dalam variabel yang diteliti secara tetap. Instrument yang digunakan dalam penelitian ini terlebih dahulu diuji cobakan pada 30 mahasiswa jurusan sosiologi dan 96 mahasiswa dari Fakultas Ekonomi Ekonomi Undiksha. Menurut ghozali (2006: 45) “ keputusan pengujian validitas instrument menggunakan taraf signifikansi (a) 0,05 dengan syarat untuk dianggap valid adalah $r$ hitung $>$ dari nilai $r$ tabel".

Kedua, Uji Reliabilitas. Setelah semua pertanyaan sudah valid, analisis selanjutnya dengan uji reliabilitas dengan cronbach's alpha. Dilakukan terhadap seluruh pertanyaan dari variabel. Caranya adalah membandingkan $r$ hasil dengan nilai konstanta $(0,60)$. Dalam uji reliabilitas sebagai nilai $r$ hasil adalah nilai alpha. Ketentuannya bila $r$ alpha $>$ konstanta $(0,60)$ maka pertanyaan tersebut reliabel. Pengolahan data dalam penelitian ini dilakukan dengan program Statistic Product and Service Solution (SPSS) for windows.
Untuk analisis data menggunakan analisis regresi sederhana dengan bantuan Statistik Product and Service Solution (SPSS) 16.0 for Window. Analisis regresi sederhana digunakan untuk mengetahui pengaruh kepercayaan konsumen terhadap minat beli secara online. Variabel terikat $(Y)$ yang digunakan dalam model analisis ini adalah minat beli dan variabel bebasnya adalah kepercayaan konsumen $(X)$

Bentuk umum persamaan regresi linear sederhana dirumuskan dengan persamaan sebagai berikut.

$$
\begin{aligned}
& Y=\alpha+b x+\varepsilon \\
& \text { (Danang, Sunyoto, 2007) } \\
& \text { Dimana: } \\
& Y=\text { Minat Beli } \\
& \alpha=\text { Konstanta } \\
& b=\text { Menunjukkan Koefisien Regresi } \\
& X=\text { Kepercayaan Konsumen } \\
& \varepsilon=\text { Variabel residual }
\end{aligned}
$$

Teknik sampling yang digunakan dalam penelitian ini adalah nonprobability sampling,yaitu dengan incidental sampling. Nonprobability sampling merupakan teknik pengambilan sampel yang tidak memberi peluang atau kesempatan yang sama bagi setiap unsur atau anggota populasi untuk dipilih menjadi sampel (Sugiyono, 2010).. 
Menurut Sugiyono (2010) incidental sampling merupakan teknik penentuan sampel yang dilakukan secara kebetulan, yaitu siapa yang secara kebetulan/insidental bertemu dengan peneliti dan dipandang orang itu cocok dijadikan sebagai sumber data, maka orang tersebut dapat digunakan sebagai sampel. Teknik pengambilan sampel dengan insidental sampling dalam penelitian ini digunakan pada saat mencari sampel dan memberikan kuisioner kepada sampel yang konsumen yang melakukan pembelian produk secara online.

Data kuantitatif yaitu data yang berbentuk angka-angka yang dapat dihitung. Dalam penelitian ini yang termasuk data kuantitatif adalah data jumlah mahasiswa sebagai konsumen yang memiliki minat untuk berbelanja secara online dan data hasil dari jawaban kuisioner mengenai kepercayaan dan minat beli.

Jenis data menurut sumbernya dalam penelitian ini menggunakan data primer dan data sekunder. Data primer adalah data yang dihasilkan untuk memenuhi kebutuhan penelitian yang sedang ditangani (Istijanto, 2006). Data primer dalam penelitian ini berupa skor hasil kuesioner mengenai kepercayaan konsumen terhadap minat beli produk pakaian secara online yang diperoleh dalam survei dengan menggunakan kuesioner yang diberikan kepada mahasiswa Fakultas Ekonomi Undiksha (FE).

Sedangkan data sekunder dalam penelitian ini adalah data berupa nama dan jumlah mahasiswa yang diperoleh dari dokumen terarsip oleh Bagian Kemahasiswaan Tata Usaha Fakultas Ekonomi Universitas Pendidikan Ganesha.

\section{HASIL DAN PEMBAHASAN Hasil}

Pada bagian hasil ini disajikan hasil penelitian mengenai besarnya pengaruh kepercayaan konsumen terhadap minat beli secara online, dengan perhitungan Statistic Product and Service Solution (SPSS) for windows release 16.0. Adapun pengaruh kepercayaan konsumen terhadap minat beli dapat dilihat pada tabel 4.1.

Tabel 2 Hasil perhitungan uji t pengaruh kepercayaan konsumen terhadap minat beli secara online

\begin{tabular}{|c|c|c|c|c|c|}
\hline \multirow[b]{3}{*}{ Model } & \multicolumn{2}{|c|}{ Unstandardized } & Standardized & \multirow[b]{3}{*}{$\mathrm{T}$} & \multirow[b]{3}{*}{ Sig. } \\
\hline & Coeff & ients & Coefficients & & \\
\hline & $B$ & Std. Error & Beta & & \\
\hline $1 \quad$ (Constant) & 19.504 & 1.951 & & 9.995 & .000 \\
\hline Kepercayaan & .227 & .076 & .296 & 2.983 & .004 \\
\hline
\end{tabular}

4.1 uji $\mathrm{t}$ terhadap variabel kepercayaan konsumen $\mathrm{X}$ didapatkan $\mathrm{t}_{\text {hitung }}>$ dari $\mathrm{t}_{\text {tabel }}$ $(2.983>1.296)$ atau signifikansi t lebih kecil dari $5 \%(0,004<0,05)$ maka secara parsial variabel kepercayaan konsumen $(X)$ berpengaruh signifikan terhadap variabel minat beli $(Y)$. besarnya pengaruh parsial kepercayaan konsumen $(\mathrm{X})$ terhadap minat beli (Y) dilihat dari nilai standardized coefficients beta sebesar 0,296 (29,6\%).

Tabel $4.1 \quad$ menggambarkan pengaruh kepercayaan konsumen terhadap minat beli produk pakaian secara online, adapun hasil persamaan regresi sederhana yaitu sebagai berikut.
Berdasarkan persamaan regresi tersebut maka dapat dijelaskan bahwa variabel kepercayaan konsumen mempunyai pengaruh yang positif terhadap minat beli secara online ( $Y$ ) dengan besarnya a 19,504, artinya setiap kenaikan $\beta_{1} X_{1} 1 \%$ mempunyai pengaruh terhadap minat beli secara online sebesar 0,227.

Dengan demikian, kepercayaan konsumen berpengaruh positif dan signifikan terhadap minat beli secara online. Pengaruh ini sangat menguntungkan bagi reseller atau pelaku penjualan online terbukti dengan banyaknya minat 
konsumen untuk melakukan pembelian secara online. Artinya, semakin tinggi kepercayaan yang diberikan konsumen maka semakin tinggi pula minat yang timbul pada diri konsumen untuk melakukan pembelian secara online. Dari hasil yang dirasakan konsumen, kepercayan belanja secara online mempengaruhi minat pembelian melalui media sosial. Persepsi konsumen dari konsistensi dan kejujuran pengecer online yang ditemukan menjadi pengaruh yang kuat pada kepercayaan konsumen di online shop. Kepercayaan konsumen terhadap internet pada online shop terjadi karena konsumen yang mulai terangsang oleh kebutuhannya dan rasa ingin tahu semakin banyak dalam pencarian informasi untuk mendapatkan yang diinginkan. Yang menjadi perhatian utama pemasar adalah sumber-sumber informasi yang menjadi acuan konsumen dan pengaruh yang kuat tiap sumber tersebut terdapat keputusan pembelian (Kotler dan Keller, 2009: 235).

Berdasarkan hal tersebut dapat disimpulkan bahwa faktor yang mempengaruhi minat beli konsumen untuk membeli suatu produk melalui media online adalah kepercayaan. Kepercayaan dianggap faktor penting dan merupakan salah satu faktor kritis dalam stimultan transaksi secara online. Kepercayaan merupakan salah satu pondasi dari bisnis apapun, suatu transaksi bisnis antara dua belah pihak atau lebih akan terjadi apabila masing-masing pihak saling mempercayai. Kepercayaan ini tidak begitu saja dapat diakui oleh pihak lain/mitra bisnis, melainkan harus dibangun mulai dari awal dan dapat dibuktikan.

\section{Pembahasan}

Berdasarkan hasil penelitian yang diperoleh, variabel kepercayaan konsumen $(X)$ terhadap minat beli secara online $(Y)$ terdapat pengaruh yang signifikan karena $P \_$value $<a ; 0,004<0,005$ menentukan taraf nyata (a) $5 \%$ dengan df $=96-2=94$, jadi $t_{\text {tabel }}$ sebesar 1,296, sedangkan nilai thitung yang diperoleh dari SPSS sebesar 2,983 sehingga $t_{\text {hitung }}>t_{\text {tabel }}$ dan keputusan yang diambil menolak Ho, besarnya pengaruh parsial kepercayaan konsumen terhadap minat beli produk pakaian secara online dapat dilihat dari nilai standardized coefficients beta sebesar 29,6\%, jadi secara parsial kepercayaan konsumen berpengaruh positif dan signifikan terhadap minat beli secara online sebesar $29,6 \%$, dalam penelitian kepercayaan konsumen, secara parsial berpengaruh positif dan signifikan, akan tetapi perlu ada peningkatan lagi karena kepercayaan konsumen masih terbilang minim, kadangkadang para konsumen tidak memiliki minat beli karena minimnya kepercayaan konsumen, dan akhirnya beralih untuk melakukan pembelian secara offline dan sebaiknya reseller meningkatkan kepercayaan konsumen sebesar 13,2\%.

Ketika seseorang berbelanja online, hal utama yang menjadi pertimbangan seorang pembeli adalah apakah website yang menyediakan online shop dan penjual online pada website tersebut dapat terpercaya. Kepercayaan pembeli terhadap website online shop terletak pada popularitas website online shop tersebut. Semakin popularitas suatu website, maka pembeli lebih yakin dan percaya terhadap reliabilitas website tersebut (Setiadi,2010). Selanjutnya, kepercayaan pembeli terhadap penjual online terkait dengan kehandalan penjual online dalam menjamin keamanan bertransaksi dan meyakinkan transaksi akan diproses setelah pembayaran dilakukan oleh pembeli. Kehandalah ini terkait dengan keberadaan penjual online. Semakin berkembangnya teknologi, semakin berkembang pula modus penipuan berbasis teknologi pada online shop. Selanjutnya, kepercayaan pembeli terhadap penjual online terkait dengan kehandalan penjual online dalam menjamin keamanan bertransaksi dan meyakinkan transaksi akan diproses setelah pembayaran dilakukan oleh pembeli. Kehandalah ini terkait dengan keberadaan penjual online. Semakin berkembangnya teknologi, semakin berkembang pula modus penipuan berbasis teknologi pada online shop.

Berdasarkan hasil penelitian yang dilakukan oleh Dikla Purbayudya Ikranegara (2017) yang menyatakan bahwa adanya pengaruh secara parsial antara kepercayaan terhadap minat beli secara online. 
Tabel 4.2 Hail Uji t pengaruh secara parsial antara kepercayaan terhadap minat beli secara online

\begin{tabular}{|c|c|c|c|c|c|}
\hline \multirow[b]{2}{*}{ Model } & \multicolumn{2}{|c|}{$\begin{array}{l}\text { Unstandardized } \\
\text { Coefficients }\end{array}$} & $\begin{array}{l}\text { Standardized } \\
\text { Coefficients }\end{array}$ & \multirow[b]{2}{*}{$\mathrm{T}$} & \multirow[b]{2}{*}{ Sig. } \\
\hline & $\mathrm{B}$ & Std. Error & Beta & & \\
\hline $1 \quad$ (Constant) & .675 & 1.909 & & .354 & .724 \\
\hline Orientasi Belanja & .161 & .043 & 284 & 3.272 & .000 \\
\hline Kepercayaan Online & 224 & .081 & 212 & 2.758 & .007 \\
\hline Pengalaman Pembelian & .229 & .072 & .298 & 4.150 & .000 \\
\hline
\end{tabular}

Pengaruh $\mathrm{X} 2$ terhadap $\mathrm{Y}$ dengan nilai t hitung sebesar $2,758>\mathrm{t}$ tabel 1,976 dan tingkat signifikansi $0,007<0,05$. Hasil menunjukkan bahwa variabel kepercayaan online secara signifikan dan positif mempengaruhi minat beli. Maka hipotesis yang kedua dikemukakan dapat diterima.

Kepercayaan menurut Gefen (2002) merupakan suatu kesediaan untuk membuat dirinya peka ke dalam tindakan yang diambil oleh pihak yang dipercaya yang didasarkan pada keyakinan. Kepercayaan dianggap faktor penting dan merupakan salah satu faktor kritis dalam stimulant transaksi secara online. Saat kepercayaan yang semakin tinggi tentu akan dapat dijadikan ukuran untuk menumbuhkan minat beli konsumen untuk bertransaksi secara online, jadi Semakin tinggi kepercayaan maka semakin tinggi minat beli. Kepercayaan yang positif tentu mempengaruhi minat konsumen untuk berbelanja secara online sebab mereka yakin bahwa penjual mampu menjalankan kegiatan bisnisnya dengan baik dan dapat terpercaya dengan cara mengirimkan produk yang dibeli kepada konsumen.

\section{SIMPULAN DAN SARAN Simpulan}

Berdasarkan hasil penelitian dan pembahasan di atas, maka dapat disimpulkan sebagai berikut: Terdapat pengaruh positif variabel kepercayaan konsumen terhadap minat beli secara online Berdasarkan hasil uji parsial (thitung) diperoleh koefisien regresi yang bernilai positif sebesar 0,227 dan t hitung sebesar 2,983 dengan signifikansi sebesar 0,004 . Hal ini menunjukkan bahwa semakin baik kepercayaan konsumen maka semakin tinggi minat beli yang dirasakan responden di di jurusan pendidikan Ekonomi Undiksha, kedua adalah Variabel kepercayaan konsumen secara parsial berpengaruh positif dan signifikan terhadap minat beli secara online sebesar $29,6 \%$.

\section{Saran}

Berdasarkan simpulan di atas, maka dapat dikemukakan saran sebagai berikut.

Bagi reseller yaitu pertama, hasill penelitian diharapkan kepada Reseller atau pelaku penjualan online hendaknya lebih menggencarkan promosi agar setiap orang lebih menyukai berbelanja secara online dan memperbaiki mutu kualitas barang yang dijual dengan cara memverifikasi para reseller yang akan menjual suatu produk tersebut apakah barang asli atau palsu. Hal ini dikarenakan jika konsumen memiliki kepercayaan untuk berbelanja secara online maka konsumen juga akan menaruh minat untuk melakukan pembelian secara online.

Kedua, reseller hendaknya lebih meningkatkan kepercayaan konsumen dengan menawarkan produk yang sesuai dengan gambar yang tertera pada situs online dan menjaga kemanan privasi yang dapat mengurangi tindakan penipuan. Hal ini dikarenakan kepercayaan dari konsumen menjadi dasar apakah konsumen tersebut akan melakukan sebuah pembelian khususnya dalam berbelanja online.

Ketiga, reseller hendaknya menindaklanjuti penipuan yang telah merugikan konsumen dan mempermudah konsumen dalam retur pembelian. Dengan adanya kepercayaan serta pengalaman konsumen yang bersifat positif maka dimasa mendatang para konsumen akan menaruh minat dalam melakukan pembelian ulang. 
Bagi peneliti selanjutnya yaitu pertama, hasil penelitian diharapkan dapat memberikan gambaran kepada peneliti selanjutnya untuk memperbaiki keterbatasan yang ada dalam penelitian ini dan memperbanyak jumlah sampel dan cara pengambilan data untuk mendapatkan hasil yang menyeluruh. Kedua, peneliti lain diharapkan dapat memperluas variabel tentang minat beli dan mengembangkan penelitian dengan memasukkan variabel lain seperti promosi, persepsi harga, persepsi manfaat, kemudahan penggunaan yang dapat mempengaruhi minat beli.

\section{DAFTAR PUSTAKA}

Andriani S. Sunarto. 2009. Hubungan Kualitas Pelayanan Kesehatan Dengan Kepuasan Pasien Rawat Inap di Badan Pelayanan Kesehatan Rumah Sakit Umum Daerah Kabupaten Magelang. Volume. 2 (1) 71-79.

Arikunto, S., 2002. Prosedur Penelitian Suatu Pendekatan Praktik. Edisi Revisi6. Jakarta: Rineka Cipta.

Arwiedya, Mochamad Ridzky. 2011. Analisis Pengaruh Harga, Jenis Media Promosi, Risiko Kinerja, dan Keragaman Produk terhadap Keputusan Pembelian Via Internet Pada Toko Online (Studi Kasus Pada Konsmen Toko Fashion Online yang Bertindak Sebagai Reseller yang Ada di Indonesia. Jurnal Ekonomi. Volume. 9 (1) 85-114.

Ashari, A. 2012. Pengaruh Promosi Penjualan Pakaian Wanita di Group Blackberry Messanger terhadap Minat Beli Mahasiswi IImu Komunikasi Universitas Hasanudin. Jurnal Ekonomi. Volume. 33 (2) 161-176.

Danang, Sunyoto. 2007. Analisis Regresi dan Korelasi Bivariat Ringkasan dan Kasus. Yogyakarta: Amara Books.

Ghozali, Imam. 2006. Aplikasi Analisis Multivariate dengan Program SPSS. Cetakan Keempat. Semarang: Badan Penerbit Universitas di Ponegoro.
Istijanto. 2006. Riset Sumber Daya Manusia. PT. Gramedia Pustaka Utama, Jakarta.

Kotler, Philip dan Keller, Kevin Lane. 2004. Manajemen Pemasaran 2. Edisi Milenium. Jakarta: PT. Ikrar Mandiri.

Kotler, Philip dan Kevin Lane Keller. 2008. Manajemen Pemasaran. Jilid 1. Jakarta: Penerbit Erlangga.

Kotler, Philip dan Kevin Lane Keller. 2009. Manajemen Pemasaran. Jilid 1. Jakarta: Penerbit Erlangga.

Kotler, Philip dan Amstrong, Gary. 2014. Prinsip-prinsip Manajemen. Edisi 14. Jilid 1. Jakarta: Erlangga.

Kurniawan, A. 2011. "Pembuatan Website Dengan Konsep Social Commercedan DocumentOriented Nosql Sebagai Failitas Berbagai Informasi". Volume. 11 (2) 117-132.

Kussujaniatun, Sri. 2001. Analisis Minat Konsumen Briket Batu Bara: Suatu Studi Empiris. Jurnal Kajian Bisnis. Volume. 11 (24) 11-20.

Pavlou, P.A. " ConsumerAcceptanceof Elektronic Commerce: Integrating Trust and Risk With The Technology Acceptence Model". International Journal of Elektronic Commerce, 7(3),. Spring 2003, pp. 101-134.

Setiadi. Nugroho J. 2008. Perilaku Konsumen: Konsep dan Implikasi Untuk Strategi dan Penelitian Pemasaran. Jakarta: Kencana

Setiadi. Nugroho J. 2010. Perilaku Konsumen. Cetakan 4. Edisi Revisi. Jakarta: Kencana.

Schiffman dan Kanuk. 2007. Perilaku Konsumen.Edisi Ke dua. Jakarta: PT. Indeks Gramedia.

Sugiyono. 2000. Metode Penelitian Bisnis. Bandung: Alfabeta. 2005. Metode Penelitian Administrasi. Bandung: Alfabeta. 2010. Metode Penelitian Pendidikan Pendekatan Kuantitatif, Kualitatif, dan $R \& D$. Bandung: Alfabeta.

$\begin{array}{cc}\text { 2013. Metode } & \begin{array}{c}\text { Penelitian } \\ \text { Pendekatan }\end{array}\end{array}$


p-ISSN : 2599 - 1418

e-ISSN : $2599-1426$
Jurnal Pendidikan Ekonomi Undiksha Volume 11 No. 1 Tahun 2019

Kuantitatif, Kualitatif, dan $R \& D$.

Bandung: Alfabeta.

Umar, Husein. 1998. Riset Akuntansi

Dilengkapi dengan Panduan

Membuat Skripsi dan Empat

Bahasan Kasus bidang

Akuntansi. Jakarta: PT Gramedia

Pustaka Utama. 